\title{
Model Dynamic Pricing untuk Penetapan Harga Tiket Pesawat Terbang Berbasis Waktu dan Persediaan Kursi dengan Mempertimbangkan Keputusan Kompetitor
}

\author{
Ahmad Rusdiansyah ${ }^{1 *}$, Rescha D. A. Putri ${ }^{1}$, Nia Puspitasari $^{1}$
}

\begin{abstract}
In the airline business nowadays the competition between airlinesis very tight. The decision of pricing of an airline will affect significantly the demand and revenue of other airlines. This study develops a model of Airline Revenue Management (ARM). We build an ARM model under competitive environment. The model considers the change of the competitor's ticket for two parallel flights and should be made based on time and seat inventory. Specifically, we develop a model of dynamic programming to obtain the optimal ticket price based on the remaining seats, the rest of the time, as well as changes in competitors' ticket prices in order to generate maximum revenue expectation. This study conducted a series of numerical experiment scenarios to demonstrate the behavior of the model to the revenue expectation.
\end{abstract}

Keywords: Airline Revenue Management, dynamic pricing, dynamic programming, expected revenue.

\section{Pendahuluan}

Perkembangan industri penerbangan turut meningkatkan tingkat persaingan antar maskapai. Persaingan yang ketat mendorong maskapai penerbangan untuk mampu merumuskan strategi dalam memaksimalkan pendapatannya. Kebijakan pengelolaan permintaan serta seluruh metodologi dan sistem yang dibutuhkan untuk membuatnya dengan tujuan memaksimalkan pendapatan disebut revenue management (RM) (Tallury dan Ryzin [13]). Penerapan revenue management di maskapai penerbangan disebut dengan Airlines Revenue Management $(A R M)$. ARM yang diterapkan di maskapai penerbangan dengan tujuan untuk memaksimalkan pendapatan melalui pengelolaan sumber daya yang dimiliki secara optimal. Dapat dikatakan ARM adalah bagaimana memperoleh pendapatan yang maksimum melalui pengelolaan kursi yang tersedia. Maskapai melakukan pengelolaan perolehan pendapatan dengan $A R M$ karena beberapa kondisi seperti permintaan kursi yang bersifat tidak pasti (unpredictable), kelebihan kursi penerbangan yang tidak laku dijual tidak dapat disimpan yang kemudian hal ini menjadi opportunity cost, fleksibilitas penumpang dalam memilih kelas atau jadwal penerbangan sehingga dapat dibagi menjadi beberapa segmen penumpang, kapasitas kursi yang disediakan yang berjumlah tetap sesuai dengan armada pesawat.

${ }^{1}$ Fakultas Teknologi Industri, Jurusan Teknik Industri, Transportation and Distribution Logistics Research Group, Laboratorium Logistics and Supply Chain Management, Institut Teknologi Sepuluh Nopember Surabaya, Kampus Keputih Sukolilo, Surabaya 60111 Indonesia. Email: arusdianz@its.ac.id, charezz@gmail.com, nia_puspita@gmail.com

*Penulis korespondensi
Dynamic pricing adalah sebuah strategi dalam $A R M$ yaitu berupa pengaturan penetapan harga yang bertujuan untuk meningkatkan pendapatan maskapai penerbangan. Penggunaan dynamic pricing sangat tepat untuk diterapkan pada industri penerbangan yang memiliki karakteristik harga tiket pesawat terbang yang dinamis. Pada waktu tertentu (sebelum waktu kebergangkatan dan selama waktu penjualan), harga tiket pesawat terbang akan berbeda dengan harga tiket pesawat terbang pada waktu sesaat sebelum keberangkatan. Pada umumnya, harga tiket pesawat terbang sangat tinggi pada saat menjelang waktu keberangkatan. Ketika waktu penjualan (selling horizon time) masih panjang, maka harga tiket pesawat terbang cenderung rendah. Penetapan harga tersebut ditentukan berdasarkan beberapa kriteria. Kriteria tersebut dapat berupa kriteria sisa waktu penjualan, sisa kursi yang belum terjual, harga kompetitor, dan lain sebagainya. Sisa kursi yang belum terjual sampai waktu penjualan berakhir akan menjadi suatu nilai (revenue) yang masih dapat diselamatkan melalui kursi yang sudah terjual dengan melakukan strategi penetapan harga secara dinamis (Lin dan Sibdari [7]). Strategi penetapan harga secara dinamis tersebut dilakukan untuk menjual kursi yang sama dengan kelas harga yang berbeda kepada konsumen yang bersedia membayar pada kelas harga tersebut. Misalnya saja, penumpang yang memesan tiket satu bulan sebelum jadwal keberangkatan memiliki peluang penerimaan yang rendah terhadap harga tiket yang tinggi. Oleh sebab itu pada waktu tersebut harga tiket masih ditetapkan rendah agar konsumen bersedia melakukan pembelian. Namun sebaliknya, penumpang yang memesan tiket pada waktu menjelang keberangkatan memiliki peluang 
penerimaan yang tinggi terhadap harga tiket yang tinggi. Penumpang tipe ini akan dapat menyelamatkan revenue yang akan hilang akibat masih adanya sisa kursi pada waktu keberangkatan dengan catatan load factor dari pesawat tersebut telah terpenuhi. Load factor adalah prosentase rata-rata dari kapasitas terisi dibandingkan keseluruhan kapasitas yang tersedia (Bazargan[1]).

Pada dynamic pricing ada beberapa strategi penetapan harga yang dapat dilakukan oleh maskapai penerbangan. Park dan Seo [9] meneliti mengenai strategi penetapan harga secara dinamis oleh maskapai penerbangan dengan mempertimbangkan customer choice behavior. Customer choice behavior merupakan klasifikasi calon penumpang berdasarkan perilaku calon penumpang dalam memilih penerbangan (Tallury dan Ryzin [14]). Park dan Seo [9] mengklasifikasikan 3 strategi penetapan harga secara dinamis yaitu yang disebut dengan strategi increasing price, decreasing price, dan fluctuating price seperti yang digambarkan pada Gambar 1. Xiao et al. [15] mengkategorikan penumpang potensial ke dalam dua kelompok berdasarkan perilaku dalam memilih yaitu time-sensitive dan pricesensitive. Penumpang time-sensitive tidak memperhatikan harga tiket yang ditawarkan dalam memilih penerbangan, sedangkan penumpang price sensitive memilih penerbangan dengan harga tiket murah dan tidak mementingkan jadwal penerbangan. Tipe konsumen yang dikelompokkan sebagai tipe time-sensitive yaitu tipe konsumen yang memilih penerbangan berdasarkan jadwal penerbangan yang sesuai dengan jadwal yang diinginkan konsumen. Tipe konsumen price-sensitive merupakan konsumen yang memilih penerbangan dengan prioritas harga tiket pesawat yang sesuai dengan tingkat penerimaan konsumen terhadap harga tiket yang ditawarkan.

Keuntungan penetapan harga secara dinamis adalah dapat melakukan penaikan atau penurunan harga sesuai dengan keinginan perusahan untuk dapat meningkatkan pendapatan perusahaan. Namun, penetapan harga pada penjelasan di atas dapat dilakukan secara bebas apabila perusahaan memonopoli pasar. Beberapa penelitian terdahulu yang melakukan penelitian mengenai model dynamic pricing pada pasar monopolistik antara lain adalah Gallego dan van Ryzin [4], Chatwin [2], Feng dan Xiao [3], Zhao dan Zheng [16], dan Lin [5]. Namun pada kenyataannya, khususnya di Indonesia, perusahaan penerbangan tidak dapat melakukan monopoli pasar. Penelitian mengenai model dynamic pricing pada dua penerbangan paralel yang dimiliki oleh satu maskapai yang sama pernah dilakukan oleh Rusdiansyah et al. [11, 12], Putri dan Rusdiansyah [10]. Selain itu, beberapa penelitian yang ada pada literatur yang membahas masalah dynamic pricing pada dua maskapai yang saling berkompetisi antara lain $\mathrm{Li}$ dan $\mathrm{Hua}[6]$, Lin dan Sibdari [7] dan Mart dan Talluri [8].

Li dan Hua [6] mengembangkan model dynamic pricing dalam menentukan harga tiket penerbangan untuk penerbangan paralel dengan pendekatan waktu kontinu dan mempertimbangkan sisa kursi. Penelitian tersebut ditujukan untuk kondisi under competition, yaitu kompetisi antar satu perusahaan penerbangan dengan perusahaan penerbangan lain yang masih dalam satu aliansi, dua perusahaan penerbangan yang menjalin kerja sama. Li dan Hua [6] membahas dynamic pricing pada dua maskapai yang juga saling berkompetisi dengan pendekatan waktu kontinu dan mempertimbangkan sisa waktu penjualan dengan dua kelas harga yang dibuka untuk masing-masing maskapai penerbangan (maskapai A dan B).

Lin dan Sibdari [7] mengembangkan model dynamic pricing dengan mempertimbangkan strategi tarif yang ditetapkan kompetitor. Model ini membuktikan eksistensi dari nash equilibrium dengan berbagai skenario. Nash equilibrium merupakan suatu strategi permainan dimana setiap strategi yang dipilih oleh masing-masing pemain adalah strategi optimum yang ditujukan untuk mengantisipasi strategi yang dilakukan oleh pemain lain hingga tercapai kondisi equilibrium. Dapat dikatakan, nash equilibrium merupakan strategi peresponan dari strategi kompetitor hingga tercapai kondisi seimbang untuk kedua pemain.

Mart dan Talluri [8] mengembangkan model dynamic pricing untuk persaingan dalam persaingan oligopoli dimana setiap pemain menjual kapasitas yang tetap dalam satu periode. Penelitian Mart dan Talluri [8] ini juga membuktikan adanya unique subgame-perfect equilibrium untuk persaingan duopoli. Model yang dikembangkan menggunakan konsep dari bid-price control. Bid-price control merupakan suatu konsep model berbasis kompetisi yang sering diterapkan pada revenue management.

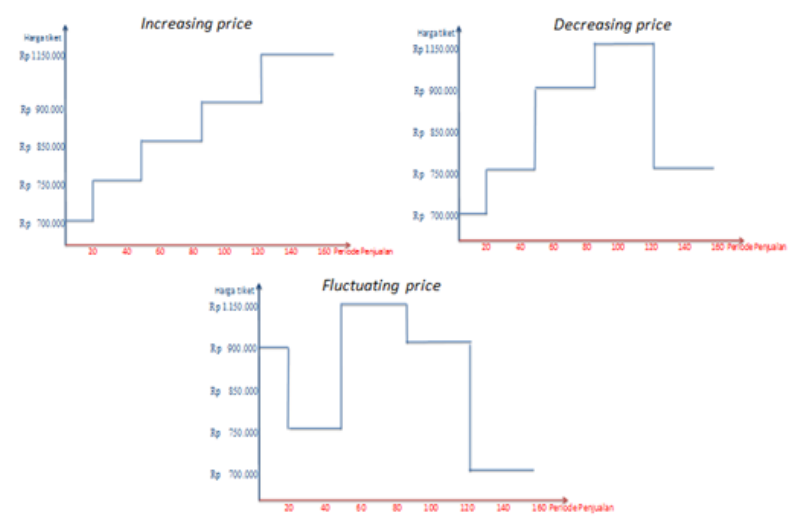

Gambar 1. Strategi penetapan harga: increasing price, decreasing price, dan fluctuating price 
Pada penelitian ini akan dibahas mengenai perubahan harga tiket pesawat terbang yang berubah secara dinamis dan diskrit pada penerbangan antar dua maskapai penerbangan (maskapai A dan B) yang saling bersaing. Berbeda dengan penelitian mengenai dynamic pricing yang ada pada literatur, pada penelitian ini, perubahan harga secara dinamis dipengaruhi oleh 3 hal yaitu sisa waktu penjualan, sisa kursi penerbangan yang belum terjual, dan juga harga yang dipasang oleh kompetitor. Maskapai penerbangan A akan merespon harga yang ditetapkan oleh penerbangan B. Penelitian ini akan membahas tentang respon yang dilakukan oleh maskapai A apabila terjadi perubahan harga yang ditetapkan kompetitor (maskapai B). Penelitian ini akan membahas perubahan harga sedemikian, hingga dapat memaksimalkan ekspektasi pendapatan maskapai A. Selain itu juga membahas tentang pengaruh dari tingkat kedatangan calon penumpang beserta periode pembukaan kelas harga terhadap ekspektasi pendapatan.

\section{Metode Penelitian}

\section{Notasi}

Berikut ini adalah notasi yang digunakan dalam formulasi model pada paper ini:

$\mathrm{t} \quad$ : menunjukkan event pada selling horizon

$[0, \mathrm{~T}] \quad: \quad 0$ merupakan awal selling horizon, sedangkan T merupakan akhir selling horizon.

$\mathrm{T}+1 \quad$ : event yang terjadi setelah selling horizon berakhir, yaitu saat waktu keberangkatan.

$\mathrm{C}_{\mathrm{A}} \quad$ : kapasitas penerbangan $\mathrm{A}$

$\mathrm{n}_{\mathrm{j}} \quad$ : jumlah tiket kursi pesawat yang tersisa pada penerbangan A pada saat $\mathrm{t}=[0, \mathrm{~T}]$

$\mathrm{C}_{\mathrm{A}-\mathrm{n}_{\mathrm{j}}} \quad$ : jumlah tiket yang telah terpesan untuk penerbangan A pada saat $\mathrm{t}=[0, \mathrm{~T}]$

$\mathrm{P} \quad: \quad \mathrm{P}=\left\{\mathrm{P}_{\mathrm{A} 1}, \mathrm{P}_{\mathrm{A} 2}, \ldots . \mathrm{P}_{\mathrm{Ak}}\right\}$ merupakan alternatif harga. Dengan asumsi $\mathrm{P}_{\mathrm{Al}}>$ $\mathrm{P}_{\mathrm{A} 2}>\ldots . .>\mathrm{P}_{\mathrm{Ak}}$.

$\mathrm{P} k i \quad$ : kelas harga ke- $k$ yang akan ditetapkan untuk penerbangan $i . i=\{\mathrm{A}, \mathrm{B}\}$.

$\mathrm{P}_{\mathrm{A}} \quad$ : harga affordable class untuk penerbangan A

$\mathrm{P}_{\mathrm{fA}} \quad$ : harga full price(flexible class) untuk penerbangan A

$\mathrm{k} \quad$ : koefisien pasangan harga salah satu penerbangan terhadap harga penerbangan lainnya.

$\mathrm{q}_{\mathrm{A}}\left(\mathrm{p}_{k i}\right) \quad$ : peluang kustomer menerima harga $\mathrm{P}$ yang ditetapkan untuk penerbangan $\mathrm{A}$.

$\mathrm{qB}_{\mathrm{B}}\left(\mathrm{p}_{k i}\right) \quad$ : peluang kustomer menerima harga $\mathrm{P}$ yang ditetapkan oleh penerbangan $\mathrm{B}$.

$\mathrm{qA}^{\prime}\left(\mathrm{p}_{k i}\right) \quad$ : peluang kustomer tidak menerima harga $\mathrm{P}$ yang ditetapkan untuk pener- bangan A akibat harga yang ditetapkan oleh penerbangan $\mathrm{B}$.

$\delta_{\mathrm{ti}} \quad$ : proporsi kustomer tipe $\mathrm{i}=1,3$ pada event ke $-\mathrm{t}$

At : tingkat kedatangan kustomer tipe $i$ pada event ke- $t$, dimana $\lambda t i=\lambda t . \delta_{\mathrm{ti}}$

af : peluang kustomer memilih kelas flexible

$\mathrm{a}_{\mathrm{A}} \quad$ : peluang kustomer memilih kelas affordable

$q_{t A} \quad$ : tingkat pembatalan pemesanan per kustomer untuk penerbangan A pada event ke- $t$

$\mathrm{BL}(p k)$ : batasan booking limit untuk kelas yang dibuka dengan harga $p k i$

I $t \quad$ : kejadian pada waktu $t$. I $t=1$ apabila kejadian terjadi; $\mathrm{I} t=0$ apabila kejadian tidak terjadi.

$\mathrm{R}(\mathrm{t}, \mathrm{nA}, \mathrm{nB})$ : ekspektasi pendapatan untuk penerbangan A selama selang waktu [t, $\mathrm{T}+1]$, jika kursi yang tersisa saat $t$, sebanyak $n A$ dan $n B$.

\section{Formulasi Model}

Model yang dibangun dalam hal ini adalah model perhitungan ekspektasi pendapatan yang diperoleh maskapai penerbangan dengan kelas harga yang dibuka adalah kelas harga $P_{A}$ untuk maskapai A (atau $P_{B}$ untuk maskapai B). Fungsi tujuan adalah memaksimalkan ekspektasi pendapatan maskapai penerbangan A (atau B) dengan variabel keputusan adalah harga kelas $P_{A}$ yang dibuka oleh maskapai $\mathrm{A}$ ( $P_{B}$ untuk maskapai B).

Penyelesaian model dynamic pricing dimulai dari event terakhir $(T+1)$ terlebih dahulu, kemudian secara berturut-turut mundur satu event hingga event ke- 0 . Total expected revenue penerbangan A dinyatakan dengan fungsi $\mathrm{R}_{0}\left(\mathrm{C}_{1}+\mathrm{v}_{1}\right)$.

\section{Model pada Event $t<T+1$}

Event $t<T+1$ merupakan horison penjualan dimana pada event ini dapat terjadi pembelian, pembatalan pembelian tiket (cancellation), dan null event. Pada event $t<T+1$ ini terdapat 3 kondisi sisa kursi yaitu kondisi ketika sisa kursi penerbangan A masih ada namun penerbangan $\mathrm{B}$ sudah habis $\left(n_{A}=0, n_{B}<0\right)$, kondisi ketika sisa kursi penerbangan A sudah habis namun penerbangan $\mathrm{B}$ masih ada $\left(n_{A}>0, n_{B}=\right.$ 0 ), dan kondisi ketika sisa kursi kedua penerbangan masih ada $\left(n_{A}>0, n_{B}>0\right)$.

Model pada Kondisi Sisa Kursi Penerbangan A Sudah Habis namun Penerbangan B Masih $\operatorname{Ada}\left(n_{A}=0, n_{B}>0\right)$

Pada kondisi ini jumlah tiket yang terpesan pada penerbangan A sudah mencapai batas reservasi 
maksimal sedangkan pada penerbangan B belum. Kejadian yang mungkin terjadi adalah tidak adanya pembelian tiket pada penerbangan A yang dinyatakan dengan persamaan:

$R_{T+1}\left(0, n_{B}\right)=0$

Persamaan (1) menunjukkan bahwa pada kondisi sisa kursi penerbangan B masih ada namun penerbangan A sudah habis, tidak ada pemasukan pendapatan untuk penerbangan A, sehingga besaran ekspektasi pendapatan penerbangan A bernilai 0 .

\section{Model pada Kondisi Sisa Kursi Penerbangan A Masih Ada namun Penerbangan B Sudah Habis $\left(n_{A}>0, n_{B}=0\right)$}

Pada kondisi ini jumlah tiket yang terpesan pada penerbangan $\mathrm{B}$ sudah mencapai batas reservasi maksimal sedangkan pada penerbangan A belum. Sehingga pada kejadian yang mungkin terjadi adalah pembelian tiket pada penerbangan A, dan null event. Selain itu pada kondisi ini alternatif kelas $(\mathrm{P})$ yang boleh dibuka untuk penerbangan A akan bergantung pada kondisi sisa kursi dan periode event-nya.

Alternatif kelas berisi kelas 1 hingga kelas $k$. Di mana kelas $k$ merupakan kelas terendah yang boleh dibuka. Nilai $k$ ditentukan dari batasan periode dan jumlah kursi (booking limit) per kelas, yaitu nilai $k$ terbesar yang memenuhi kondisi $t<t(p k)$ dan $n_{A}<$ $B L(p k)$. Selanjutnya dilakukan perhitungan ekspektasi pendapatan dan ditentukan optimal pricing untuk penerbangan $\mathrm{A}\left(p_{A}\right)$ dari alternatif harga tiket $\left(\mathrm{p}_{1}, \mathrm{p}_{2}, \ldots, p k\right)$. Pada kondisi ini, jika ada kustomer tipe III yang datang, akan langsung memilih penerbangan A karena tiket untuk penerbangan $\mathrm{B}$ telah terjual habis hingga batas maksimum reservasi.

$R_{T+1}\left(n_{A}, 0\right)=\max _{p A \in P}\left\{\alpha_{A} \cdot \lambda t\left[\left(q A+q A^{\prime}\right) \cdot[p A+\right.\right.$ $\left.\left.\left.R_{t}\left(n_{A}-1,0\right)\right]\right]+\left[\left(1-q A-q A^{\prime}\right) \cdot R_{t}\left(n_{A}, 0\right)\right]\right\}+$ $\left\{\alpha_{f} \cdot \lambda t\left[\left(q f A+q f A^{\prime}\right) \cdot\left[p f A+R_{t}\left(n_{A}-1,0\right)\right]\right]+\right.$ $\left.\left[\left(1-q f A-q f A^{\prime}\right) \cdot R_{t}\left(n_{A}, 0\right)\right]\right\}+\left[\left(1-\lambda t \cdot\left(\alpha_{A}+\right.\right.\right.$ $\left.\left.\left.\alpha_{f}\right)\right) \cdot R_{t}\left(n_{A}, 0\right)\right]$

Persamaan (2) menunjukkan bahwa pada kondisi sisa kursi penerbangan A masih ada namun penerbangan $\mathrm{B}$ sudah habis, karena calon penumpang pasti memilih penerbangan A maka akan ada 3 kemungkinan kejadian.

\section{Model pada Kondisi Sisa Kursi Kedua Pener- bangan Masih Ada $\left(n_{A}>0, n_{B}>0\right)$}

Pada kondisi ini jumlah tiket yang terpesan pada penerbangan A dan B belum mencapai batas reservasi. Kejadian yang mungkin terjadi adalah pem- belian tiket pada penerbangan A, serta null event. Pada kondisi ini, jika ada kustomer tipe III yang datang, akan dilihat harga kelas dikedua penerbangan terlebih dahulu. Penumpang tipe III akan membeli tiket pada penerbangan dengan harga terendah. Peluang calon penumpang dalam memilih harga yang ditetapkan oleh penerbangan A dibandingkan dengan harga pada penerbangan $\mathrm{B}$ ditentukan dengan peluang $q_{A}(\mathrm{P} k i)$. Calon penumpang yang beralih ke penerbangan $B$ karena harga pada penerbangan $\mathrm{B}$ lebih murah daripada penerbangan A ditentukan dengan peluang $q_{A}{ }^{\prime}(\mathrm{P} k i)$. Apabila calon penumpang tidak melakukan pembelian baik itu penerbangan A maupun B karena harga yang dirasa terlalu tinggi ditentukan dengan peluang $q o(\mathrm{P} k i)$.

$R_{T+1}\left(n_{A}, n_{B}\right)=\max _{p A \in P}\left\{\alpha_{A} \cdot \lambda t[((q A) \cdot[p A+\right.$

$\left.\left.R_{t}\left(n_{A}-1, n_{B}\right)\right]\right)+\left(q A^{\prime}\right) \cdot R_{t}\left(n_{A}, n_{B}-1\right)+$

$\left.\left(1-q A-q A^{\prime}\right) \cdot R_{t}\left(n_{A}, n_{B}\right)\right]+\alpha_{f A} \cdot \lambda t[((q f A) \cdot[p f A+$

$\left.\left.\left.R_{t}\left(n_{A}-1, n_{B}\right)\right]\right)-(1-q f A) \cdot R_{t}\left(n_{A}-1, n_{B}\right)\right]+$

$\left.\left[\left(1-\lambda t \cdot\left(\alpha_{A}+\alpha_{f}\right)\right) \cdot R_{t}\left(n_{A}, n_{B}\right)\right]\right\}$

Persamaan (3) menunjukkan bahwa pada kondisi sisa kursi penerbangan A dan B belum mencapai batas maksimal reservasi, ada dua kemungkinan kejadian dan null event. Masing-masing kejadian tersebut memiliki kontribusi terhadap pendapatan maskapai penerbangan seperti pada kondisi lainnya.

\section{Hasil dan Pembahasan}

\section{Percobaan Numerik}

Untuk menguji model yang telah dikembangkan dilakukan percobaan numerik dengan parameter awal sebagai berikut: kapasitas kursi untuk kedua penerbangan sama, $\mathrm{C} 1=\mathrm{C} 2=80$. Tiket dapat dijual dengan empat alternatif harga tiket dan satu harga tiket penuh untuk flexible class. Selling horizon dibagi menjadi $\mathrm{T}=150$ events, dimana proporsi untuk kustomer tipe I dan tipe III adalah $(\alpha 1, \alpha 3)=(33 \%$, $33 \%)$. Peluang pelanggan tipe 1 untuk memilih flexible class adalah 0,3. Dalam percobaan numerik terdapat satu harga full price, dan empat alternatif kelas harga $\{$ pi1, pi2, pi3, pi4\} dengan i=A,B untuk dynamic pricing. Pada Tabel 1. disajikan daftar harga yang ditawarkan. Contoh untuk kenaikan kelas harga disajikan pada Tabel 2. Daftar harga dan kenaikan kelas harga tersebut mengacu pada harga tiket yang ditawarkan dan periode kenaikan harga yang diterapkan oleh salah satu maskapai penerbangan di Indonesia untuk rute JakartaSurabaya.

Dalam praktiknya, kenaikan kelas harga tidak hanya berdasarkan periode saja namun juga ber- 
dasarkan sisa kursi yang tersedia. Sebagai contoh, apabila telah mencapai periode kenaikan kelas harga maka harga tiket yang ditawarkan oleh maskapai penerbangan akan naik. Namun, walaupun periode kenaikan kelas harga tersebut belum terca pai bisa saja maskapai penerbangan menaikkan kelas harganya karena sisa kursi yang tersedia pada kelas harga yang lebih rendah telah habis. Pada Tabel 3. ditampilkan kenaikan kelas harga berbasis sisa persediaan kursi. Pada Gambar 2 diilustrasikan melalui grafik mengenai kenaikan kelas harga berdasarkan periode dan sisa kursi penerbangan.

Pada Gambar 2. digambarkan grafik peningkatan harga tiket bedasarkan periode dan sisa kursi penerbangan. Garis Tebal biru menunjukkan perubahan harga tiket. Perubahan harga tiket ini terjadi apa bila telah mencapai batas periode ataupun batas sisa kursi (dalam gambar diberikan simbol BL yaitu booking limit). Batas periode digambarkan dengan garis putus-putus berwarna hitam sedangkan batas sisa kursi digambarkan dengan garis putus-putus berwarna merah.

Data yang tidak kalah pentingnya yang diperlukan dalam percobaan numerik ini adalah tingkat kedatangan pelanggan. Tingkat kedatangan pelanggan dalam penelitian ini merupakan parameter input dimana akan dilakukan perubahan parameter input tersebut untuk menganalisa hasil dari model yaitu ekspektasi pendapatan maskapai penerbangan. Tingkat kedatangan pelanggan untuk setiap periode yang digunakan dalam penelitian ini ditampilkan dalam Tabel 4.

Tabel 1. Daftar kelas harga

\begin{tabular}{lc}
\hline & Harga \\
\hline Full price & $\mathrm{Rp} 1.150 .000,00$ \\
$78 \%$ dari full price & $\mathrm{Rp} 900.000,00$ \\
$74 \%$ dari full price & $\mathrm{Rp} 850.000,00$ \\
$65 \%$ dari full price & $\mathrm{Rp} 750.000,00$ \\
$61 \%$ dari full price & $\mathrm{Rp} 700.000,00$ \\
\hline
\end{tabular}

Tabel 2. Kenaikan kelas harga berdasar periode

\begin{tabular}{lll}
\hline & Kenaikan harga & Periode $\mathrm{t}=150$ \\
\hline Rp & $900.000,00$ & $112-150$ \\
Rp & $850.000,00$ & $76-112$ \\
Rp & $750.000,00$ & $38-75$ \\
Rp & $700.000,00$ & $1-37$ \\
\hline
\end{tabular}

Tabel 3. Kenaikan kelas harga berdasar sisa kursi

\begin{tabular}{llc}
\hline & Kenaikan harga & Sisa Kursi \\
\hline Rp & $900.000,00$ & 15 kursi \\
Rp & $850.000,00$ & 30 kursi \\
Rp & $750.000,00$ & 55 kursi \\
Rp & $700.000,00$ & 80 kursi \\
\hline
\end{tabular}

Tabel 4. Tingkat kedatangan pelanggan

\begin{tabular}{ll}
\hline \multicolumn{2}{c}{ Kedatangan } \\
\hline Periode $t=1 \mathrm{~s} / \mathrm{d} 37$ & 0,594594595 \\
Periode $t=38 \mathrm{~s} / \mathrm{d} 75$ & 0,729729730 \\
Periode $t=76 \mathrm{~s} / \mathrm{d} 112$ & 0,783783784 \\
Periode $t=113 \mathrm{~s} / \mathrm{d} 150$ & 0,864864865 \\
\hline
\end{tabular}

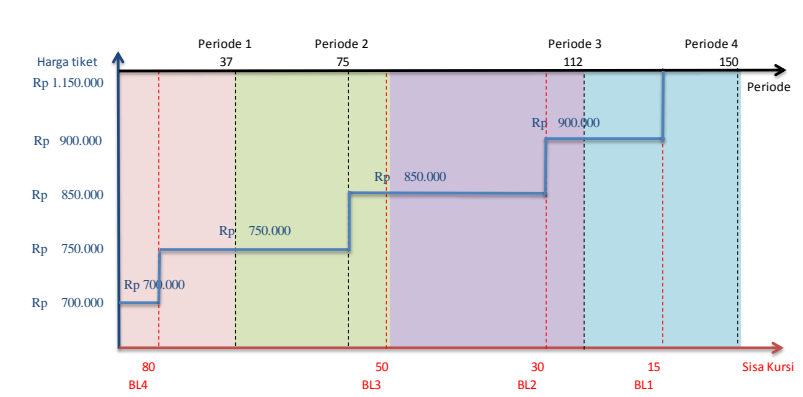

Gambar 2. Grafik peningkatan harga tiket berdasarkan periode dan sisa kursi penerbangan

Percobaan numerik pada paper ini dibagi menjadi 2 percobaan penetapan optimal pricing yaitu percobaan numerik untuk penerbangan A sebagai follower kompetitor dan sebagai perespon competitor.

\section{Percobaan Numerik untuk Penerbangan A Sebagai Follower Kompetitor}

Pada percobaan ini, maskapai A dalam menetapkan harga mengikuti harga yang telah ditentukan oleh kompetitor yaitu maskapai B (maskapai A sebagai follower). Sebagai contoh ketika maskapai B membuka harga $\mathrm{p}_{4}$ pada periode awal maka maskapai $\mathrm{A}$ sebagai follower akan mengikuti dengan melakukan pembukaan harga di kelas harga $\mathrm{p}_{4}$.

Pada percobaan numerik ini dilakukan percobaan scenario pembukaan kelas harga oleh maskapai B (kompetitor) yang kemudian akan diikuti oleh maskapai A (follower) dengan tiga skenario pembukaan kelas harga sebagai berikut:

Skenario 1: perubahan kelas harga dengan menggunakan kombinasi harga yaitu kombinasi $\mathrm{p}_{4-} \mathrm{p}_{3-} \mathrm{p}_{2}-\mathrm{p}_{1}$

Skenario 2: perubahan kelas harga menggunakan kombinasi harga $\mathrm{p}_{3-} \mathrm{p}_{1-} \mathrm{p}_{4}-\mathrm{p}_{2}$

Skenario 3: merupakan perubahan kelas harga dengan kombinasi harga $\mathrm{p}_{2}-\mathrm{p}_{1-} \mathrm{p}_{3}-\mathrm{p}_{4}$

Skenario ini mengikuti 3 strategi yang diangkat oleh penelitian Park dan Seo [9] yaitu strategi increasing, decreasing, dan fluctuating. Selain itu skenario ini mewakili kombinasi pembukaan kelas harga yang banyak diterapkan oleh maskapai penerbangan di Indonesia. Skenario 1 merupakan skenario pembukaan kelas harga yang terus naik (increasing) yaitu maskapai penerbangan akan melakukan pembukaan kelas harga dari harga terendah menuju ke harga tertinggi seiring dengan berkurangnya 
waktu penjualan dan berkurangnya sisa kursi penerbangan. Skenario 2 merupakan skenario pembukaan kelas harga yang naik turun (fluctuating) yaitu maskapai penerbangan melakukan perubahan harga naik dan turun untuk memperoleh pendapatan yang lebih dengan merespon kompetitornya. Skenario 3 merupakan skenario pembukaan kelas harga yang cenderung menawarkan harga kelas yang lebih rendah pada periode mendekati jadwal penerbangan (decreasing). Skenario ini biasa digunakan oleh maskapai penerbangan untuk memperoleh lebih banyak penumpang pada akhir-akhir periode penjualan apabila sisa kursi penerbangan tersebut masih ada.

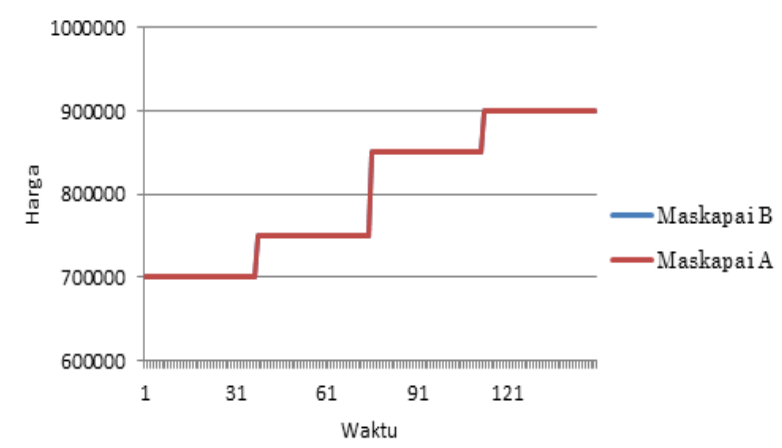

Gambar 3. Perubahan kelas harga yang dibuka pada maskapai A sebagai follower dengan skenario 1

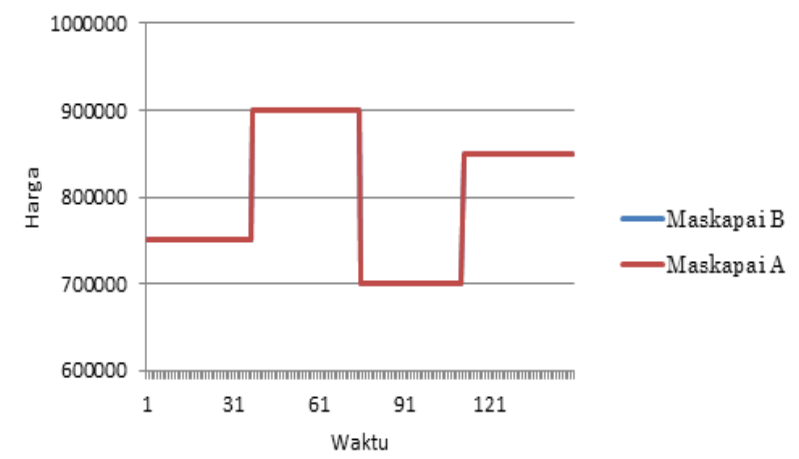

Gambar 4. Perubahan kelas harga yang dibuka pada maskapai A sebagai follower dengan skenario 2

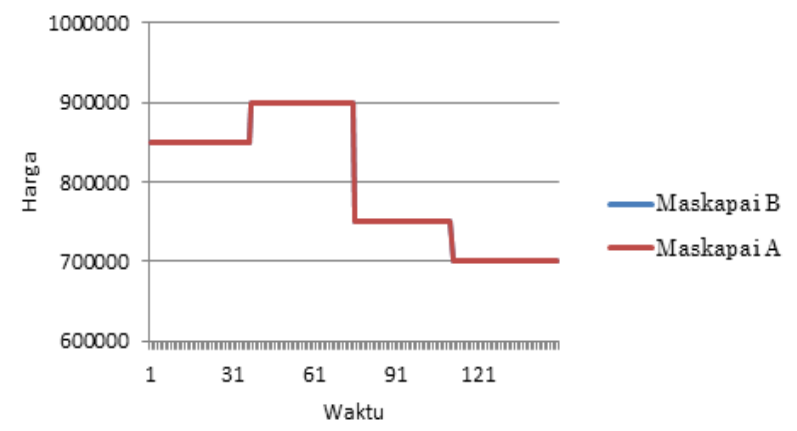

Gambar 5. Perubahan kelas harga yang dibuka pada maskapai A sebagai follower dengan skenario 3

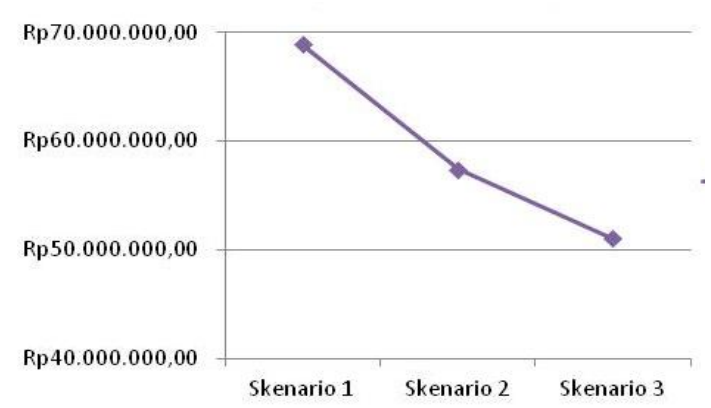

Gambar 6. Perbandingan ekspektasi pendapatan dari 3 skenario

Hasil percobaan numerik untuk Maskapai A sebagai follower dengan ketiga skenario yang telah dijelaskan di atas ditampilkan dalam Gambar 3-5 sedangkan perbandingan ekspektasi pendapatan dari ketiga skenario tersebut ditampilkan dalam Gambar 6 .

Skenario 1 dalam percobaan ini memiliki pola penetapan harga yang teratur dimana harga terendah dibuka di awal kemudian diikuti dengan harga di kelas atasnya, dan semakin mendekati hari keberangkatan harga yang dibuka akan semakin tinggi. Pada skenario 2, memiliki pola penetapan harga dimana harga kelas yang lebih tinggi dibuka di awal periode kemudian kelas harga yang dibuka akan menurun ketika periode $t$ semakin bertambah. Dari hasil percobaan, pola penetapan harga yang diterapkan dalam skenario 1 menghasilkan ekspektasi pendapatan yang lebih tinggi dibandingkan dengan ekspektasi pendapatan pada skenario 2 maupun skenario 3. Hal ini terjadi karena ketika maskapai A bertindak sebagai follower maka pola penetapan pembukaan kelas harga ditentukan dengan mengikuti pola penetapan harga yang digunakan oleh kompetitor. Dalam hal ini ekspektasi pendapatan yang diperoleh pun tergantung dengan pola penetapan harga yang ditentukan oleh maskapai B sebagai kompetitor. Apabila pola penetapan harga kompetitor tersebut menyebabkan ekspektasi yang didapatkan lebih tinggi seperti pada skenario 1, maka secara tidak langsung menguntungkan maskapai A yang melakukan penetapan harga sebagai follower dan begitu pula sebaliknya.

Pada kenyataannya skenario penetapan harga dengan bertindak sebagai follower akan menyulitkan. Hal ini dikarenakan dibutuhkan informasi lengkap mengenai harga yang dipasang oleh kompetitor, karena dengan begitu pendapatan yang diperoleh dapat semaksimal mungkin. Namun informasi mengenai kompetitor di tengah ketatnya persaingan akan sangat susah didapatkan. Di samping itu, apabila perubahan penetapan harga maskapai kompetitor bersifat berubah-ubah dan tidak pasti, juga akan mengakibatkan maskapai yang bertindak sebagai follower harus terus melakukan penyesuaian. 


\section{Percobaan Numerik untuk Penerbangan A sebagai Perespon Kompetitor}

Pada percobaan numerik ini, penetapan harga oleh maskapai B direspon oleh maskapai A dengan kombinasi perubahan kelas harga yang berbeda-beda. Dapat dikatakan, skenario ini merupakan skenario perespon terhadap harga kompetitor.

Pada percobaan ini dilakukan percobaan numerik untuk mengetahui seperti apakah pola perubahan kelas harga maskapai A sebagai perespon yang menghasilkan ekspektasi pendapatan terbesar dengan bermacam-macam pola perubahan harga kompetitor. Skenario harga yang digunakan dalam percobaan numerik ini sama dengan skenario harga pada percobaan numerik pada sub bab sebelumnya yaitu terdapat 3 skenario (increasing, decreasing, dan fluctuating). Namun, pada percobaan numerik ini, Maskapai A bertindak sebagai perespon sehingga, apabila terdapat 3 skenario harga maka maskapai A mempunyai 3 alternatif respon yang disebut dengan kombinasi I, II, dan III.

Skenario 1: Maskapai B sebagai kompetitor melakukan perubahan harga dengan kombinasi pertama yaitu $\mathrm{p}_{4-} \mathrm{p}_{3}-\mathrm{p}_{2}-\mathrm{p}_{1}$. Maskapai A dalam hal ini merespon perubahan harga tersebut dengan kombinasi I ( $\left.\mathrm{p}_{4^{-}} \mathrm{p}_{3^{-}} \mathrm{p}_{2^{-}} \mathrm{p}_{1}\right)$, kombinasi II ( $\mathrm{p}_{4^{-}} \mathrm{p}_{1^{-}} \mathrm{p}_{3^{-}}$ $\left.\mathrm{p}_{2}\right)$ dan kombinasi III ( $\left.\mathrm{p}_{3^{-}} \mathrm{p}_{2^{-}} \mathrm{p}_{1^{-}} \mathrm{p}_{4}\right)$. Gambar 7 mengilustrasikan perubahan harga maskapai A dan B pada skenario1.

Skenario 2: Maskapai B sebagai kompetitor melakukan perubahan harga dengan kombinasi kedua yaitu $\mathrm{p}_{3-} \mathrm{p}_{1-} \mathrm{p}_{4-} \mathrm{p}_{2}$. Maskapai A dalam hal ini merespon perubahan harga tersebut dengan kombinasi I ( $\left.\mathrm{p}_{4-} \mathrm{p}_{3^{-}} \mathrm{p}_{2^{-}} \mathrm{p}_{1}\right)$, kombinasi II ( $\mathrm{p}_{4^{-}} \mathrm{p}_{1^{-}} \mathrm{p}_{3^{-}}$ $\left.\mathrm{p}_{2}\right)$ dan kombinasi III ( $\left.\mathrm{p}_{3^{-}} \mathrm{p}_{2^{-}} \mathrm{p}_{1^{-}} \mathrm{p}_{4}\right)$. Gambar 8 mengilustrasikan perubahan harga maskapai A dan B pada skenario 2 .

Skenario 3: Maskapai B sebagai kompetitor melakukan perubahan harga dengan kombinasi ketiga yaitu $\mathrm{p}_{2^{-}} \mathrm{p}_{1^{-}} \mathrm{p}_{3^{-}} \mathrm{p}_{4}$. Maskpai A dalam hal ini merespon perubahan harga tersebut dengan kombinasi I ( $\left.\mathrm{p}_{4}-\mathrm{p}_{3-} \mathrm{p}_{2-} \mathrm{p}_{1}\right)$, kombinasi II ( $\left.\mathrm{p}_{4}-\mathrm{p}_{1-}-\mathrm{p}_{3-} \mathrm{p}_{2}\right)$ dan kombinasi III ( $\left.\mathrm{p}_{3-}-\mathrm{p}_{2}-\mathrm{p}_{1-} \mathrm{p}_{4}\right)$. Gambar 9 mengilustrasikan perubahan harga maskapai A dan B pada skenario 3.

Hasil percobaan numerik untuk ekspektasi pendapatan untuk skenario 1 , 2, dan 3 perubahan harga kompetitor, dengan 3 kombinasi perubahan harga Maskapai A sebagai perespon ditampilkan pada Gambar 10, 11, dan 12.

Pada skenario 1 kompetitor, kombinasi $\mathrm{p}_{4-} \mathrm{p}_{3-} \mathrm{p}_{2-} \mathrm{p}_{1}$ dan $\mathrm{p}_{4-} \mathrm{p}_{2}-\mathrm{p}_{1}-\mathrm{p}_{3}$ merupakan skenario yang mengha- silkan pendapatan paling tinggi. Pada $\mathrm{p}_{4-} \mathrm{p}_{2-} \mathrm{p}_{1-} \mathrm{p}_{3}$ terjadi spoilage di awal periode pertengahan, namun pada akhir periode membuka harga lebih rendah dibanding kompetitor, sehingga di akhir periode calon penumpang lebih memilih harga dibanding kompetitor. Pada $\mathrm{p}_{3}-\mathrm{p}_{2-} \mathrm{p}_{1-} \mathrm{p}_{4}$ terjadi spoilage ketika $\mathrm{P}_{3}, \mathrm{P}_{2}$ dan $\mathrm{P}_{1}$ dibuka pada awal periode dimana calon penumpang menginginkan harga lebih rendah dan memilih kompetitor yang membuka harga $\mathrm{P}_{4}, \mathrm{P}_{3}$ dan $\mathrm{P}_{2}$, serta terjadi kehilangan kesempatan untuk memperoleh pendapatan lebih besar di akhir periode karena harga rendah $\mathrm{P}_{4}$ dibuka di akhir periode.

Pada variasi perubahan harga kompetitor skenario kedua yaitu $\mathrm{p}_{3-} \mathrm{p}$ 1- $^{-} \mathrm{p}_{4}-\mathrm{p}_{2}$, diketahui bahwa skenario pola perubahan maskapai A yang menghasilkan ekspektasi pendapatan yang paling besar adalah

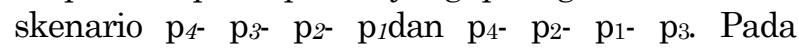
kombinasi $\mathrm{p}_{4-} \mathrm{p}_{3-}-\mathrm{p}_{2-} \mathrm{p}_{1}$ terjadi spoilage di periode pertengahan, namun tergantikan dengan eskpetasi pendapatan dari $\mathrm{P}_{4}$ dan $\mathrm{P}_{3}$ yang dibuka di awal periode, dimana calon penumpang lebih memilih ini dibandingkan kompetitor yang membuka harga tinggi.

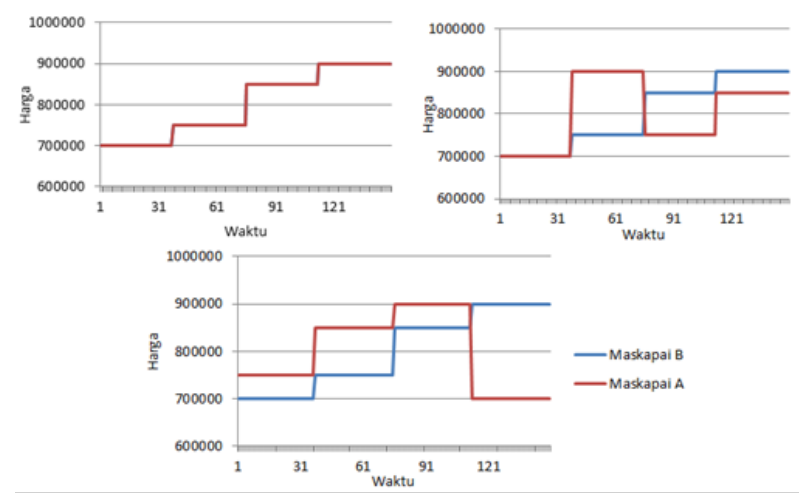

Gambar 7. Perubahan Harga Maskapai A sebagai perespon Maskapai B untuk Skenario 1 (dari kiri ke kanan bawah: Maskapai A merespon dengan kombinasi I, kombinasi II, kombinasi III)

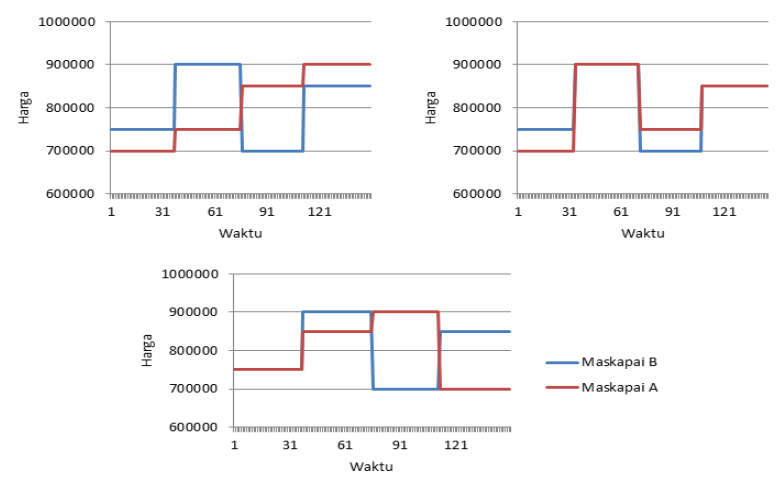

Gambar 8. Perubahan Harga Maskapai A sebagai perespon Maskapai B untuk Skenario 2 (dari kiri ke kanan bawah: Maskapai A merespon dengan kombinasi I, kombinasi II, kombinasi III) 


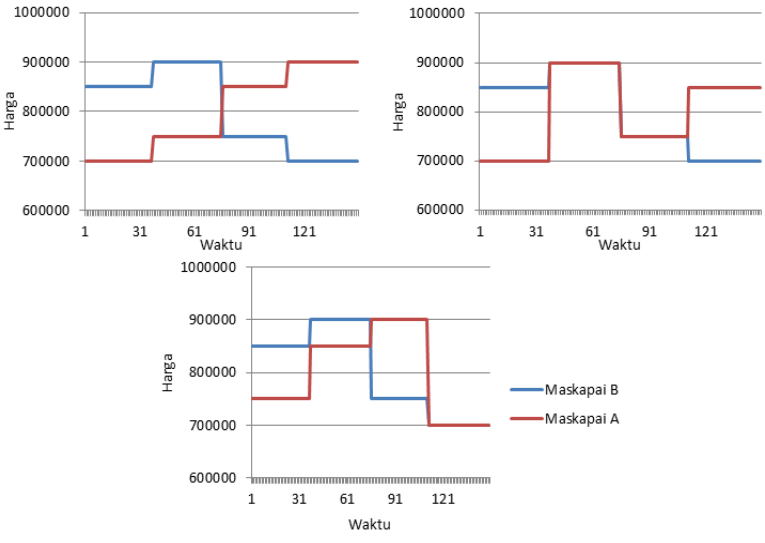

Gambar 9. Perubahan Harga Maskapai A sebagai perespon Maskapai B untuk Skenario 3 (dari kiri ke kanan bawah: Maskapai A merespon dengan kombinasi I, kombinasi II, kombinasi III)

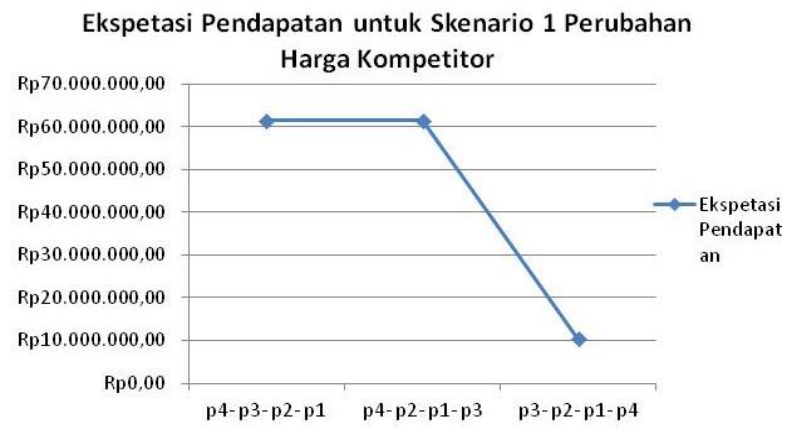

Gambar 10. Ekspektasi pendapatan skenario 1 perubahan harga competitor

Ekspetasi Pendapatan untuk Skenario 2 Perubahan Harga Kompetitor

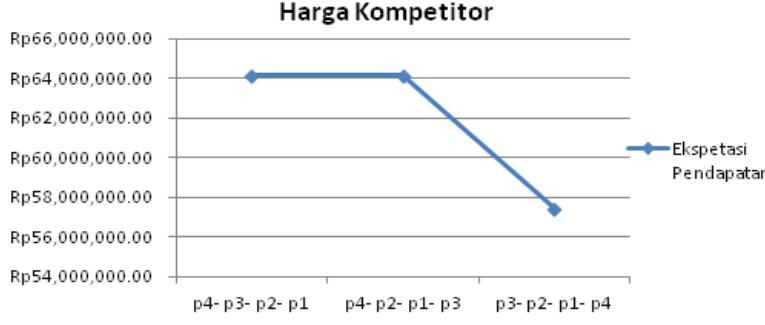

Gambar 11. Ekspektasi pendapatan skenario 2 perubahan harga competitor

\section{Ekspetasi Pendapatan untuk Skenario 3 Perubahan Harga Kompetitor}

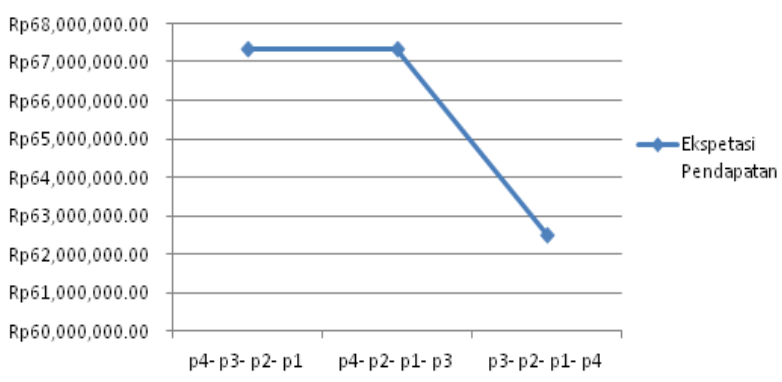

Gambar 12. Ekspektasi pendapatan skenario 3 perubahan harga competitor
Pada kombinasi $\mathrm{p}_{4}-\mathrm{p}_{2}-\mathrm{p}_{1}-\mathrm{p}_{3}$ terjadi spoilage di akhir periode pertengahan, dan tergantikan dengan pembukaan $\mathrm{P}_{3}$ di awal periode dibanding kompetitor yang membuka $\mathrm{P}_{2}$. Pada kombinasi $\mathrm{p}_{3}-\mathrm{p}_{2}-\mathrm{p}_{1-} \mathrm{p}_{4}$ juga terjadi spoilage $d i$ akhir periode pertengahan, dan juga terjadi kehilangan kesempatan mendapat ekseptasi pendapatan lebih besar karena $\mathrm{P}_{4}$ dibuka di akhir periode.

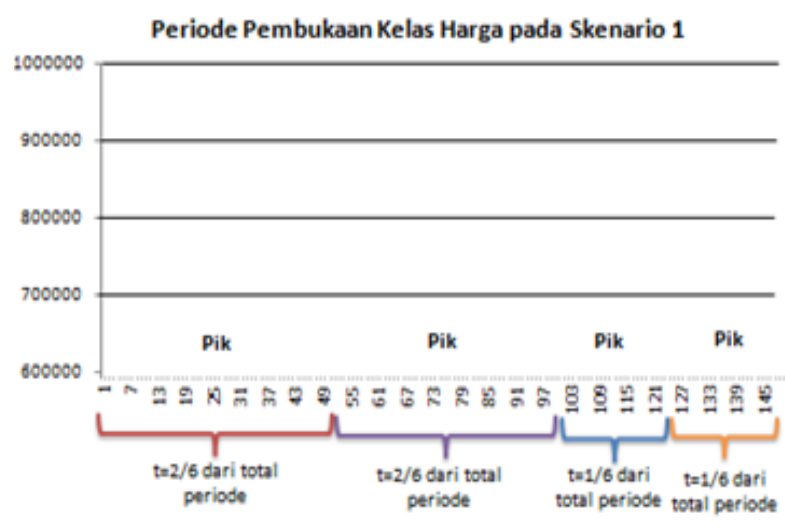

Gambar 13. Skenario 1 untuk variasi periode pembukaan kelas harga

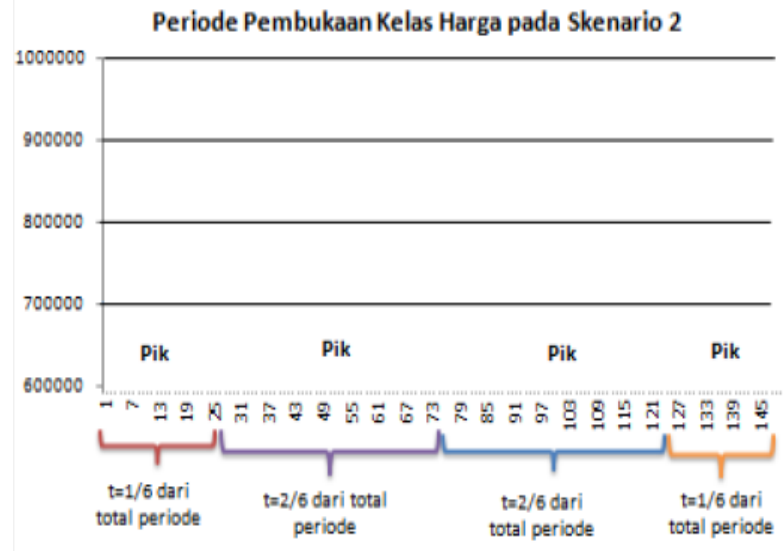

Gambar 14. Skenario 2 untuk variasi periode pembukaan kelas harga

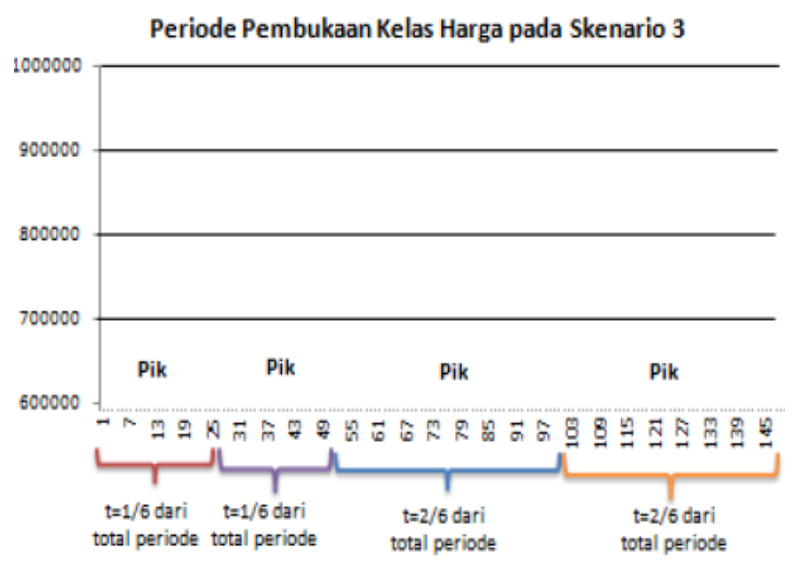

Gambar 15. Skenario 3 untuk variasi periode pembukaan kelas harga 


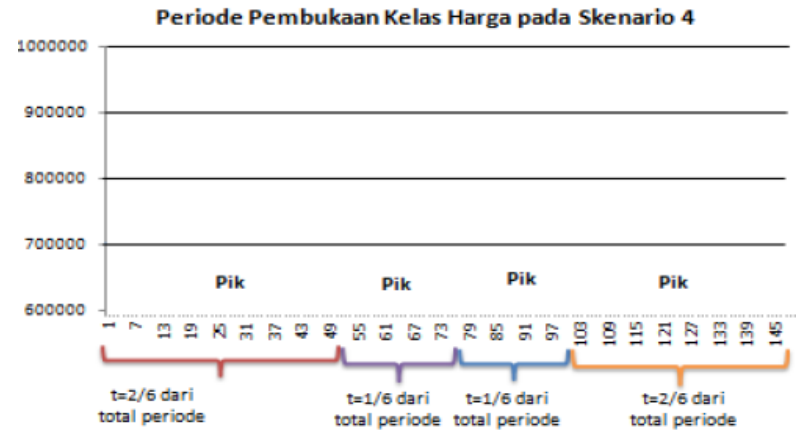

Gambar 16. Skenario 4 untuk variasi periode pembukaan kelas harga

Pada variasi perubahan harga kompetitor skenario ketiga adalah pola perubahan $\mathrm{p}_{2-} \mathrm{p}_{1^{-}} \mathrm{p}_{3-} \mathrm{p}_{4}$. Pada pola perubahan harga kompetitor ini, ekspektasi pendapatan maksimum didapat ketika maskapai memasang skenario pola perubahan yaitu $\mathrm{p}_{4-} \mathrm{p}_{3^{-2}} \mathrm{p}_{2^{-}}$ $\mathrm{p}_{1}$ dan $\mathrm{p}_{4-} \mathrm{p}_{2^{-}} \mathrm{p}_{1-} \mathrm{p}_{3}$. Pada kombinasi $\mathrm{p}_{4-} \mathrm{p}_{3^{-}} \mathrm{p}_{2-} \mathrm{p}_{1}$ terjadi spoilage di periode akhir, namun tergantikan dengan eskpetasi pendapatan dari $\mathrm{P}_{4}$ dan $\mathrm{P}_{3}$ yang dibuka di periode awal, dimana calon penumpang lebih memilih ini dibandingkan kompetitor yang membuka harga jauh tinggi. Penggunakan kombinasi $\mathrm{p}_{4-}-\mathrm{p}_{2}-\mathrm{p}_{1}-\mathrm{p}_{3}$ menyebabkan terjadi spoilage di periode akhir, dan tergantikan dengan pembukaan $\mathrm{P}_{4}$ di awal periode dibanding kompetitor yang membuka $\mathrm{P}_{1}$. Pada kombinasi $\mathrm{p}_{3-}-\mathrm{p}_{2}-\mathrm{p}_{1}-\mathrm{p}_{4}$ terjadi spoilage di akhir periode pertengahan, dan juga terjadi kehilangan kesempatan mendapat ekspektasi pendapatan lebih besar karena $\mathrm{P}_{4}$ dibuka di akhir periode.

\author{
Percobaan Numerik untuk Penerbangan A \\ dengan Variasi Periode Pembukaan Kelas \\ Harga
}

Pada percobaan numerik ini dilakukan perhitungan ekspektasi pendapatan untuk maskapai A dengan variasi periode pembukaan kelas harga maskapai A. Pada percobaan ini, periode pembukaan kelas harga maskapai A akan diubah-ubah dengan tujuan untuk mengetahui pengaruhnya terhadap ekspektasi pendapatan. Perubahan periode pembukan kelas harga dilakukan untuk masing-masing kelas harga. Ekspektasi pendapatan yang diperoleh dari percobaan untuk skenario yang telah dilakukan (Tabel 5-7).

Dari setiap variasi skenario periode untuk masingmasing kelas harga pada setiap peresponan untuk masing-masing kombinasi, didapatkan hasil bahwa dengan melakukan pembukaan kelas harga dengan skenario 3, dimana periode pembukaan lebih panjang di periode akhir, akan menghasilkan ekspektasi pendapatan yang terbesar dibandingkan dengan skenario lainnya. Hal ini dikarenakan dengan melakukan pembukaan kelas harga di akhir periode, maka pendapatan yang diperoleh dengan membuka berapapun alternatif kelas harga akan semakin besar, mengingat bahwa pada periode akhir jumlah calon penumpang yang datang lebih besar. Hal ini juga terjadi karena periode yang diperpanjang di sesuaikan dengan alokasi kursi yang juga ditambahkan jumlahnya, sehingga alokasi kursi lebih banyak akan menghasilkan ekspektasi pendapatan yang lebih besar.

Tabel 5. Ekspektasi pendapatan skenario peresponan terhadap kombinasi 1 kompetitor

\begin{tabular}{ccccc}
\hline \multirow{2}{*}{$\begin{array}{c}\text { Skenario perespon dengan kombinasi kompetitor } \\
\text { (p3-p1-p4-p2) }\end{array}$} & \multicolumn{3}{c}{$\begin{array}{c}\text { Ekspektasi pendapatan untuk skenario variasi periode pembukaan } \\
\text { kelas (Ribuan Rp) }\end{array}$} \\
\cline { 2 - 5 } & Skenario 1 & Skenario 2 & Skenario 3 & Skenario 4 \\
\hline p4-p3-p2-p1 & 42100 & 58312 & 87963 & 61152 \\
p4-p2-p1-p3 & 42100 & 58312 & 87674 & 64090 \\
p3-p2-p1-p4 & 6426 & 5293 & 11774 & 8342 \\
\hline
\end{tabular}

Tabel 6. Ekspektasi pendapatan skenario peresponan terhadap kombinasi 2 kompetitor

\begin{tabular}{ccccc}
\hline \multirow{2}{*}{$\begin{array}{c}\text { Skenario perespon dengan kombinasi kompetitor } \\
\text { (p3-p1-p4-p2) }\end{array}$} & \multicolumn{4}{c}{$\begin{array}{c}\text { Ekspektasi pendapatan untuk skenario variasi periode pembukaan } \\
\text { kelas (Ribuan Rp) }\end{array}$} \\
\cline { 2 - 5 } & Skenario 1 & Skenario 2 & Skenario 3 & Skenario 4 \\
\hline p4-p3-p2-p1 & 46394 & 62695 & 93735 & 70546 \\
p4-p2-p1-p3 & 46394 & 62695 & 93049 & 70546 \\
p3-p2-p1-p4 & 43369 & 58865 & 86226 & 64696 \\
\hline
\end{tabular}

Tabel 7. Ekspektasi pendapatan skenario peresponan terhadap kombinasi 3 kompetitor

\begin{tabular}{ccccc}
\hline \multirow{2}{*}{$\begin{array}{c}\text { Skenario perespon dengan kombinasi kompetitor } \\
\text { (p3-p1-p4-p2) }\end{array}$} & \multicolumn{4}{c}{$\begin{array}{c}\text { Ekspektasi pendapatan untuk skenario variasi periode pembukaan } \\
\text { kelas (Ribuan Rp) }\end{array}$} \\
\cline { 2 - 5 } & Skenario 1 & Skenario 2 & Skenario 3 & Skenario 4 \\
\hline p4-p3-p2-p1 & 43973 & 59289 & 89768 & 67662 \\
p4-p2-p1-p3 & 43973 & 59289 & 88871 & 67662 \\
p3-p2-p1-p4 & 39469 & 54149 & 86226 & 60055 \\
\hline
\end{tabular}


Tabel 8. Skenario untuk tingkat kedatangan tiap periode

\begin{tabular}{cccc}
\hline & $\begin{array}{c}\text { Skenario 1 } \\
\text { (orang) }\end{array}$ & $\begin{array}{c}\text { Skenario 2 } \\
\text { (orang) }\end{array}$ & $\begin{array}{c}\text { Skenario 3 } \\
\text { (orang) }\end{array}$ \\
\hline Periode 1 & 22 & 20 & 18 \\
Periode 2 & 27 & 25 & 24 \\
Periode 3 & 29 & 30 & 32 \\
Periode 4 & 32 & 35 & 36 \\
\hline
\end{tabular}

Tabel 9. Ekspektasi pendapatan pada variasi tingkat kedatangan

\begin{tabular}{ccccc}
\hline \multicolumn{2}{c}{ Kursi } & \multicolumn{3}{c}{ Ekspektasi pendapatan } \\
\hline A & B & Skenario 1 & Skenario 2 & Skenario 3 \\
\hline 80 & 80 & 61402 & 65643 & 68295 \\
60 & 80 & 59325 & 62001 & 64365 \\
80 & 60 & 65187 & 69775 & 72476 \\
70 & 80 & 61400 & 67313 & 68270 \\
80 & 70 & 63159 & 63159 & 70345 \\
\hline
\end{tabular}

Dapat dilihat pula bahwa dengan melakukan berbagai skenario variasi periode pembukaan harga, skenario sebagai perespon yakni p4- p3- p2- p1 dan p4- p2- p1- p3 konsisten dalam menghasilkan ekspektasi pendapatan yang selalu lebih besar dibanding skenario perespon $\mathrm{p} 3-\mathrm{p} 2-\mathrm{p} 1-\mathrm{p} 4$.

\section{Percobaan Numerik untuk Penerbangan A dengan Variasi Kedatangan Calon Penumpang}

Pada percobaan numerik ini dilakukan perhitungan ekspektasi pendapatan untuk maskapai A dengan mempertimbangkan faktor kedatangan calon penumpang. Percobaan numerik ini bertujuan untuk mengetahui pengaruh dari kedatangan calon penumpang dalam setiap periodenya terhadap ekspektasi pendapatan yang dihasilkan. Berikut adalah Tabel 8 yang menunjukkan jumlah kedatangan calon penumpang di setiap periodenya untuk masing-masing skenario dengan jumlah penumpang yang datang untuk masing-masing skenario tersebut adalah sama yaitu 110 orang (sesuai kapasitas kursi pesawat). Skenario 1, 2, 3 berbeda dalam tingkat kedatangan calon penumpangnya. Skenario 1 dibuat kedatangan penumpang pada periode awal lebih banyak dibandingkan skenario lain namun pada periode akhir paling sedikit. Pada skenario 3, kedatangan calon penumpang pada periode awal paling sedikit dibandingkan skenario lain namun pada periode akhir, kedatangan calon penumpangnya paling banyak dibandingkan periode lainnya. Skenario 2 merupakan skenario normal yaitu kedatangan calon penumpang dibuat rata namun dalam hal ini periode akhir selalu memperoleh kedatangan penumpang yang lebih banyak sesuai dengan yang sering terjadi pada dunia nyata.

Setelah dilakukan perhitungan untuk masingmasing skenario, didapatkan ekspektasi pendapatan untuk masing-masing variasi kedatangan calon penumpang yang dapat dilihat dalam Tabel 9. Diketahui bahwa tingkat kedatangan calon penumpang semakin mendekati hari keberangkatan semakin besar. Semakin banyaknya kedatangan ini menandakan bahwa peluang calon penumpang yang melakukan pembelian di periode akhir semakin besar. Hal ini akan berpengaruh terhadap ekspektasi pendapatan yang diperoleh. Namun penetapan perubahan kelas harga akan turut mempengaruhi ekspektasi pendapatan.

Apabila maskapai membuka kelas harga rendah di akhir periode tentunya akan mengakibatkan kesempatan untuk memperoleh ekspektasi pendapatan yang tinggi hilang akibat membuka harga rendah di akhir periode. Pada skenario yang dilakukan dalam percobaan numerik ini menggunakan skenario perubahan kelas harga dimana kelas harga terendah dibuka pada awal periode dan kelas harga tertinggi dibuka diakhir periode. Setelah dilakukan percobaan variasi tingkat kedatangan didapatkan skenario 3 memiliki hasil ekspektasi pendapatan yang paling tinggi. Hal ini dikarenakan pada skenario 3, jumlah orang yang datang pada akhir periode lebih besar dibandingkan kedua skenario lainnya. Oleh karena itu, dapat disimpulkan dengan penetapan harga tertinggi di akhir periode, faktor tingkat kedatangan yang besar di akhir periode akan sangat berpengaruh pada hasil ekspektasi pendapatan.

\section{Simpulan}

Penelitian ini mengembangkan model dynamic pricing pada dua maskapai penerbangan (maskapai A dan B) yang saling bersaing berbasis persediaan kursi dan waktu dengan mempertimbangkan perubahan harga kompetitor. Penetapan harga dengan bertindak sebagai follower dan perespon akan menghasilkan ekspektasi pendapatan yang bergantung pada pola perubahan harga dari kompetitor. Maskapai penerbangan A akan merespon harga yang ditetapkan oleh maskapai penerbangan B. Penelitian ini akan memberikan rekomendasi mengenai respon yang sebaiknya dilakukan oleh maskapai A apabila terjadi perubahan harga yang ditetapkan kompetitor (maskapai B) sedemikian, hingga dapat memaksimalkan ekspektasi pendapatan maskapai A. Berdasarkan hasil percobaan numerik diperoleh kesimpulan bahwa maskapai penerbangan A baik sebagai follower maupun sebagai perespon terhadap competitor (maskapai penerbangan B) akan memperoleh ekspektasi pendapatan yang lebih tinggi jika menggunakan strategi increasing price $\left(\mathrm{P}_{4}-\mathrm{P}_{3}-\mathrm{P}_{2}-\mathrm{P}_{1}\right)$. Selain itu, priode pembukaan kelas harga dan tingkat kedatangan calon penumpang mempengaruhi ekspektasi pendapatan yang dihasilkan. 


\section{Ucapan Terima Kasih}

Penelitian ini didanai oleh dana hibah kompetensi DIKTI tahun 2013. Penulis menyampaikan terima kasih kepada para reviewer yang telah memberikan saran dan komentar yang sangat membangun dalam proses penulisan paper ini.

\section{Daftar Pustaka}

1. Bazargan, M., Airlines Operations and Scheduling 2nd Edition, Embry-Riddle Aeronautical University, USA: Ashgate, 2010.

2. Chatwin R. E., Optimal Dynamic Pricing of Perishable Products with Stochastic Demand and a Finite Set of Prices, European Journal of Operational Research, 125, 2000, pp. 149-174.

3. Feng Y, and Xiao B., A Continuous-time Yield Management Model with Multiple Prices and Reversible Price Changes, Management Science, 46(5), 2000, pp. 644-657.

4. Gallego G, and van Ryzin G J., A Multi-product, Multi-resource Pricing Problem and Its Applications to Network Yield Management, Operations Research, 45(1), 1997, pp. 24-41.

5. Lin K. Y., A Sequential Dynamic Pricing Model and Its Application, Naval Research Logistics, 51(4), 2004, pp. 501-521.

6. Luo, Li., and Peng, Ji-Hua, Dynamic Pricing Model for Airline Revenue Management under Competition, Systems Engineering - Theory \& Practice, 27(11), 2007, pp. 15-25.

7. Lin, K. Y., Soheil, Y., and Sibdari., Dynamic Pricing Competition with Discrete Customer Choices, European Journal of Operational Research, 197, 2009, pp. 969-980.

8. Mart, V., and Tallury, K. T., Dynamic Price Competition with Fixed Capacities, IESE Business School, Av. Barcelona, Final Project, 2010.
9. Park, Changkyu and Seo, Junyong, Seat Inventory Control for Sequential Multiple Flights with Customer Choice Behavior, Computers \& Industrial Engineering, 61, 2011, pp. 1189-1199.

10. Putri, R. D. A., and Rusdiansyah, A., Comparison Analysis of Time and Seat Inventory-based Decisions in Joint Dynamic Pricing for Two Parallel Flights Considering Overbookings, Cancellation, and No-show passengers. Proceeding of APIEMS Conference 2012, PhuketThailand.

11. Rusdiansyah A., Mariana D., Pradhana H., and Wessiani N., Model of Dynamic Pricing for Two Paralel Flight with Multiple Fare Classes Based on Passanger Choice Behavior, Jurnal Teknik Industri, Universitas Kristen Petra Surabaya, 12(1), 2010, pp. 9-16.

12. Rusdiansyah, A., Pradhana, H., and Wessiani, P., Joint Dynamic Pricing Model for Two Parallel Flights Considering Overbooking, Cancellations, and No-show Customers, Journal of the Eastern Asia Society for Transportation Studies, 9, 2011, pp. 2113-2128.

13. Tallury, K. T., and van Ryzin, G., The Theory and Practice of Revenue Management, Kluwer Academic Publisher, Boston, 2004.

14. Tallury, K. T., and van Ryzin, Revenue Management under a General Discrete Choice Model of Consumer Behavior, Management Science, 50(1), 2004, pp. 15-33.

15. Xiao, Y. B., Chen, J., and Liu, X. L., Joint Dynamic Pricing for Two Paralel Flight Based on Passenger Choice Behavior, System Engineering Theory \& Practice, 28, 2008, pp. 46-55.

16. Zhao, W.,and Zheng Y. S., Optimal Dynamic Pricing for Perishable Assets with Non-homogeneous Demand, Management Science, 46, 2000, pp. 375-388. 